\title{
Talking Baseball When There Is No Baseball: Reporters and Fans During the COVID-19 Pandemic
}

\author{
Alexander L. Curry and Tiara Good \\ Western Oregon University
}

\begin{abstract}
The 2020 coronavirus outbreak led Major League Baseball to cancel spring training and postpone the start of the regular season. Although baseball stopped, reporters continued to write about baseball, and fans continued to talk about baseball. But with no games being played, what were they writing and talking about? More than a simple examination of what these two groups are saying, the authors also examined why their focus has turned to particular topics and themes. Through a textual analysis of Entertainment and Sports Programming Network (ESPN) baseball headlines and Reddit posts, the authors found writers jolted out of their routines, yet still framing many of their 2020 stories to focus on the actions of players. For fans, they uncovered conversations that, in many ways, read like friends mourning the loss of a loved one.
\end{abstract}

Keywords: coronavirus, media framing, textual analysis

On March 12, 2020, one day after the World Health Organization declared COVID-19 a global pandemic, Major League Baseball (MLB) canceled the remainder of its spring training games and postponed the start of its regular season. Two months later-at the time of this writing-MLB remains suspended. Discussions about starting the season are ongoing, but it is still unknown whether a 2020 season will be played at all.

In spite of baseball's absence, articles on the sport continue to be written, and fans continue to engage online with one another. We are interested in understanding how the present pandemic has altered the nature of baseball-related reporting and fandom. To this end, we set out to answer two questions: when there is no baseball, (a) what do baseball reporters write about, and (b) what do baseball fans talk about? In addition to an examination of what these two groups are saying, we also examined why their focus has turned to particular topics and themes.

To accomplish this task, we gathered and analyzed two data sets. For our examination of baseball reporters, we collected the headlines of every baseball article published on the Entertainment and Sports Programming Network (ESPN) website —ESPN.com—in March and April 2019 and 2020 (2,252 headlines in total; 1,780

The authors are with the Communication Studies Dept., Western Oregon University, Monmouth, OR, USA. Curry (currya@mail.wou.edu) is corresponding author. 
headlines from 2019 and 472 headlines from 2020). ${ }^{1}$ To understand what baseball fans were saying, we turned to Reddit, a social networking website that consists of subreddits, or groups centered on a particular topic. There is one subreddit dedicated to each of the 30 MLB teams, in which members of the subreddit post conversation topics. Unlike a team's Facebook page or Twitter account, which is managed by team employees, the subreddits are managed by fans, and the active, member-driven participation in the subreddits made them an ideal locale to uncover what fans were talking about during the pandemic. ${ }^{2}$ In May 2020, using the software program Data Miner (Software Innovation Lab LLC, Seattle, WA), we scraped all 30 team subreddits, collecting from each subreddit the previous month's posts (a total of 5,818 unique posts). ${ }^{3}$ With the time constraints of this special issue in mind, we chose to focus on ESPN headlines (as opposed to the entire article text) and the titles of the subreddit posts (instead of the entire post and adjoining comments). Knowing that the headlines/titles in our data set should offer a fair representation of the article/post as a whole (Dor, 2003; Gilbert 2013), we were satisfied that this approach would give us an accurate look at baseball talk among the two groups under examination.

Both data sets were analyzed using a qualitative textual analysis. This method can involve a range of actions, from adhering to a meticulous set of rules to a more informal and interpretive reading of the texts (Fürsich, 2009). Working under the aforementioned time constraints, we chose the latter strategy. Through numerous close, independent readings of these two data sets, we uncovered emerging frames and themes. These themes were refined through discussions between the authors and further readings of the text. Together, this qualitative process allowed us to bring to light themes embedded within the data sets (Chamaz, 2006).

The results of our textual analysis yielded a number of themes (and frames in our analysis of the headlines), some of which were expected and others surprising. For the reporters, we found writers jolted out of their routines, yet still framing many of their 2020 stories to focus on the actions of players. For fans, we found that hidden in their wide-ranging posts, there was a strong undercurrent of conversation that, in many ways, read like friends mourning the loss of a loved one. We addressed these two groups and our findings in the sections below.

\section{Baseball Writers}

The way reporters write about baseball frames and shapes the experience of the game for fans. Frames set agendas, perpetuate particular views, and offer salience to certain aspects of baseball (Kuypers, 2010; Reese, 2001). Frames consistently appear and "convey thematically consonant meanings across ... time" (Entman, 1991, p. 7). Headlines frame the article (Pan \& Kosicki, 1993) and baseball headlines, in particular, offer a quick summation of what the reader needs to know about games, player status, general MLB information, and so on. Combining a textual and framing analysis (see Kuypers, 2010) of headlines from March and April 2019 and 2020, we present overarching frames and underlying themes related to the two seasons.

\section{9}

The months of March and April 2019 offer a baseline for what reporting looks like at the start of a typical MLB season. Using this baseline, we found one predominant 
theme used throughout 2019: business. The frame had a heavy focus on players, including transactions, injuries, surgeries, up-and-coming prospects, and so forth. Commoditization of athletes is a result of this type of framing and is part of the reporting style and business of baseball. Furthermore, the business frame was consistently oriented around teams and, especially, around the games themselves (i.e., game updates). The business frame and its underlying themes allow the reporter to connect the reader deeply with the baseball conversation.

Within the business frame, the theme of player updates appeared most often, and salaries, trades, and injuries were significant underlying themes. Articles about, for example, star players Mike Trout and Bryce Harper were prominently positioned, due to the large contracts both players signed that year. A March 1 headline read, 'Trout: 'Haven't even thought about' contract." Shortly after, a March 7 headline doubled up on both star players: "Harper stands by comments on recruiting Trout." The player theme also focused on speculation about future performance: "What Bryce Harper's amazing 2015 season tells us about his career path" (March 8). In short, these and other similar headlines prioritized individual player performance and speculation about future performance as a salient and click-worthy way to talk about baseball.

The business frame also orients readers to focus on the games. A typical gamefocused headline, of which there were many, read: "Cozart, La Stella lead Angels past Cubs 6-5" (April 13). These headlines appeared often and consisted of players whose performance stood out, team names, and the final score all layered together. Numerous slight variations on this game-focused headline were present in the 2019 data set.

\section{0}

The cadence of the 2019 season, with its focus on a business frame that features players, teams, and games, is present only for the first few days of March 2020. After the first mention of the virus, the rhythm is scattered quickly. The business frame, with its player update themes, narrowed to focus on surgeries, rehabilitation from injuries, and how players are staying in shape while baseball is on hiatus. Ultimately, without games, talk about baseball lost its rhythm, and three new frames emerged: virus, philanthropy, and rankings.

Before turning to these new frames, it is noteworthy to mention that the player update theme did not disappear, but instead, adjusted to the postponed season. For example, the headline "Yu Darvish can guess your blood type" (March 11) sticks to the expected player-centric theme by featuring a celebrity-status pitcher, but deviates in that it does not include team or game updates. On March 16, the headline "Panik added to major league roster by Blue Jays" offers a more expected way to talk about baseball. In spite of the lack of play, events are still occurring that call for the player update theme: "Astros' Verlander has groin surgery, out 6 weeks" (March 17) and "Olney: Timing of Sale's surgery makes perfect senseeven if the season weren't on hold" (March 19).

The virus frame first appeared on March 9-“"Virus delays start of Japan pro baseball league" - and persists throughout the remainder of our data set, with the word "coronavirus" or "virus" in 29 headlines during this time period. That March 9 headline referenced the virus' impact on another league, but a headline the next 
day confirmed that worries over the virus had come to MLB: "Leagues close locker rooms over virus concerns" (March 10). On March 12, MLB postponed the regular season, and on March 13, a headline read, "What we know as MLB delays start of season because of coronavirus." The "what we know" suggests that there are many looming unknowns, something prevalent in many of the virus-framed headlines.

At this point, the virus frame took on a status of being consistently present, and it began to interplay with other themes. For example, the player theme showed up in the virus frame on March 23: "Ten MLB players to follow on social media during the coronavirus shutdown." Reporters, at the mercy of the virus's effects and without the rhythmic supply of game-centric information, offer readers an opportunity to still follow players, even if not for in-game performances.

The novel philanthropy frame focuses on the charitable actions of players, teams, and the league as a whole. A typical example is seen in this March 15 headline: "Reds' Bauer stages wiffle ball game for charity." Actions taken by the league and teams are demonstrated in this March 17 headline: "MLB teams pledge \$30M to help ballpark workers." In the end, the philanthropy frame not only operates to orient readers to favorably view their institution and teams across the league during uncertain times, but with its focus on players engaging in acts of service and charity, it also operates as another way for reporters to maintain a focus on the personalities of the players. This frame is consistent with the player-focused headlines of 2019.

Finally, the ranking frame was evident throughout our 2020 headlines. "ESPN's MLB Rank, 100-1: Baseball's top players for 2020" (March 11) and "Today-would-have-been-Opening Day MLB Power Rankings" (March 27) are typical examples. Both employ player and team frames. The latter example is noteworthy in its sentiment that something is being missed. This idea of missing something shows up in other headlines, as well as talk among baseball fans, which will be described below. Relatedly, there are headlines, many of which that fall under the ranking frame, that suggest to readers that they should recall times in the past, when the normal rhythms of baseball still existed: "The biggest one-hit wonders for every National League team" (April 2), and "One wild record you probably didn't know for all 30 MLB teams" (April 29). This memory-evoking theme is not only dominant in headlines, but also among fans.

\section{Baseball Fans}

A quick look at our data set of subreddit posts would reveal a seeming randomness, as the topics jump from pandemic-related ticket refunds to a discussion about a 2015 World Series game to posts about finding a box of old baseball cards in the back of a closet. As we kept reading, however, we noticed patterns: there were frequent expressions of grief related to the lack of baseball; there were shared memories (e.g., talking about former stars, treasured in-stadium recollections, old ticket stubs from random games, favorite jerseys, etc.); speculation about what a return to baseball —if there would be a return at all-would look like; and there were practical concerns (e.g., ticket refunds, stadium construction, Tommy John surgeries, etc.). These themes-grief, memory, speculation, and practical concernssuggest to us that baseball fans on Reddit are navigating the postponed season as they would the loss of a loved one. 
We acknowledge, of course, that missing a baseball season is nowhere as serious as the death of a family member or close friend. Looking to literature on psychology and bereavement, however, we do see similarities between how fans are handling MLB's absence and how the bereaved deal with a loved one's passing. These similarities include experiencing grief (Littlewood, 1992; Zisook \& Shear, 2013), the recalling of memories and the cherishing of mementoes in an effort to "keep alive" those who have died (Currier, Holland, \& Neimeyer, 2008; Massimi \& Baecker, 2011), speculation about what happens to loved ones after death and the possibility of reunion in a different realm or afterlife (Stephenson, 1985), and the many practical concerns that accompany death (e.g., organizing a funeral, paying for the casket, notifying banks and credit card companies, etc.). With these thoughts in mind, we share exemplars for each of the four themes.

\section{Grief}

One of the clearest themes that emerged was that of grief, and posts were peppered with such expressions as "My dad started tearing up ... he's not taking this no baseball thing very well" (Nationals, April 2), "We're all sad" (Dodgers, April 12), and "I miss baseball. A lot" (Indians, April 2). This idea of missing something was prevalent and included people who missed being at the ballpark; missed the instadium concessions; and who simply missed baseball, their favorite team, and the connections baseball creates with others: "I've never missed baseball so much" (Diamondbacks, April 16), "I miss our boys" (Mets, May 16), and "I miss all of you" (Dodgers, 19 April).

\section{Memories}

Nearly every team had one post that asked the following question: "Why are you fans of the [team name]?" Variations on this question included "What is your first Cubs memory?" (Cubs, April 8), "What were your favorite lighthearted moments during an A's game?" (Athletics, April 14), and "Favourite Jays moments?" (Blue Jays, April 18). Some posts asked others to join in recalling a specific player, game, or moment: "1984 MVP Willie Hernandez" (Tigers, April 19), "Re-watching the Reds sweep of the Astros in 2019 and that walk-off will never make me not happy" (Reds, April 29), "Vlad Jr's debut was 1 year ago today" (Blue Jays, April 26), and "8 years ago today, Chris Davis made his MLB pitching debut. 2.0 IP, 2 H, 0 ER, OBB, 2 SO" (Orioles, May 6). Other posts mentioned old ticket stubs, baseball cards, ball caps, autographed balls, and so on: "Dad works for the Sox and is an avid collector. He's been doing some organizing since the lockdown. Thought I'd share a small fraction of his collection" (White Sox, April 16) and "Found an envelope of old ticket stubs ... 9yr old me wrote fun game facts on the back of all the tickets. 9yr old me also sucked at spelling" (Indians, April 20).

\section{Speculation}

These posts center on speculation of when (or if) baseball will return, and if it does, how it might be different. "Border closed ... . Home games all played in Buffalo?" (Blue Jays, May 13), "Whole MLB season in Arizona?!-current temps already in 
the 100s-I don't see how this will work" (Red, April 26), "MLB expected to enforce 'Universal DH' rule, pending player approval" (Mets, May 13), "So if there is no baseball season ... ." (Astros, April 2), and "Will we see a season this year?" (Mets, April 27).

\section{Practical Concerns}

In spite of the sense of loss they felt, people had practical concerns that needed to be addressed, including how to get refunds for games that were not going to be played: "Any season ticket holders successfully get a refund for this season?" (Brewers, April 29) and "Does anyone know what is going to happen with tickets for games that had been cancelled?" (Athletics, April 16). Other practical concerns focused on player surgeries and how they would recover, as well as conversations centered on free agency, like this one: "A lot of people are rightfully focused on losing Mookie if no baseball is played in 2020 but what do you think the Dodgers will do with all the other expiring contracts like Turner, Treinen, Pederson, Kike, Baez" (Dodgers, April 6).

The motivation for why fans would approach baseball's absence like the death of a loved one comes into clearer focus as we consider that one of the more significant aspects of dealing with death is the identity transition and transformation that the bereaved undertake (Neimeyer, Prigerson, \& Davies, 2002). For example, a spouse is integral to a person's individual and social identity, and when that spouse dies, Neimeyer et al. (2002) stated that the identity of the bereaved undergoes a transition (e.g., from spouse to widow) and a transformation (e.g., a recasting of their relationship to the deceased). All the while, the bereaved tries to maintain a connection to the spouse, holding on to memories and mementos in an effort to maintain a sense of identity and keep a part of the deceased alive. Knowing that sports can play a central role in a fan's individual and social identity (Gwinner \& Swanson, 2003; Sutton, McDonald, Milne, \& Cimperman, 1997; Wann \& Branscombe, 1993), it is no wonder that we find similarities between how fans react to an unprecedented separation from a beloved sport and how people react to the passing of a loved one.

\section{Conclusion}

In summary, baseball reporters in 2020 adhered to 2019's predominant business frame as best they could, frequently invoking the player update theme, including when they wrote about the virus and about philanthropic acts. They, like fans, also sought to highlight memories of prepandemic players and games, while at the same time, marking events, like opening day, that were being missed. Fans bereft of games as opening day came and went expressed their grief and sought to fill the void by keeping baseball alive through memories, speculations, and the practical concerns of being a fan during the COVID-19 pandemic.

In the end, MLB will be back, either with a truncated season this year or a more normal-looking season beyond 2020. With baseball's return, we anticipate that reporters will dive back into cherished and expected routines, and headlines will once again take on the business frame seen in 2019, complete with a focus on player, team, and game updates. Fans will likely follow suit, with conversations 
centered on grief and memories replaced by posts that break down the latest amazing play, missed call, or player acquisition. The virus and MLB's temporary absence will, like so many other things in baseball, become a footnote in its long history. Until then, reporters and fans will continue to write, grieve, and talk baseball.

\section{Notes}

1. ESPN provides a searchable database of all its MLB news headlines from 2003 to the present. See http://www.espn.com/mlb/news/archive.

2. The Red Sox subreddit has the largest membership (69,326), and the Marlins the smallest $(7,693)$. Total membership for all team subreddits combined is 817,847 .

3. We would have preferred to analyze the Reddit posts using the same 2019/2020 comparisons that we did for the ESPN articles, but scraping the older Reddit posts was not possible due to the restrictions of Reddit's current application programming interface.

\section{References}

Chamaz, K. (2006). Constructing grounded theory. Thousand Oaks, CA: SAGE.

Currier, J.M., Holland, J.M., \& Neimeyer, R.A. (2008). Making sense of loss: A content analysis of end-of-life practitioners' therapeutic approaches. Omega, 57(2), 121-141. PubMed ID: 18680886 doi:10.2190/OM.57.2.a

Dor, D. (2003). On newspaper headlines as relevance optimizers. Journal of Pragmatics, 35(5), 695-721. doi:10.1016/S0378-2166(02)00134-0

Entman, R.M. (1991). Framing U.S. coverage of international news: Contrasts in narratives of the KAL and Iran air incidents. Journal of Communication, 41(4), 6-27. doi:10. $1111 / \mathrm{j} .1460-2466.1991 . t b 02328 . x$

Fürsich, E. (2009). In defense of textual analysis: Restoring a challenged method for journalism and media studies. Journalism Studies, 10(2), 238-252. doi:10.1080/ 14616700802374050

Gilbert, E. (2013, February). Widespread underprovision on Reddit. Paper presented at the 2013 Computer Supported Cooperative Work Conference, San Antonio, TX.

Gwinner, K., \& Swanson, S.R. (2003). A model of fan identification: Antecedents and sponsorship outcomes. Journal of Services Marketing, 17(3), 275-294. doi:10.1108/ 08876040310474828

Kuypers, J.A. (2010). Framing analysis from a rhetorical perspective. In P. D'Angelo \& J.A. Kuypers (Eds.), Doing news framing analysis: Empirical and theoretical perspectives (pp. 286-311). New York, NY: Routledge.

Littlewood, J. (1992). Aspects of grief: Bereavement in adult life. New York, NY: Routledge.

Massimi, M., \& Baecker, R.M. (2011, May). Dealing with death in design: Developing systems for the bereaved. Paper presented at the 2011 Conference on Human Factors in Computing Systems, Vancouver, BC.

Neimeyer, R.A., Prigerson, H.G., \& Davies, B. (2002). Mourning and meaning. American Behavioral Scientist, 46(2), 235-251. doi:10.1177/000276402236676

Pan, Z., \& Kosicki, G.M. (1993). Framing analysis: An approach to news discourse. Political Communication, 10(1), 55-75. doi:10.1080/10584609.1993.9962963

Reese, S. (2001). Prologue-Framing public life: A bridging model for media research. In S. Reese, O.H. Gandy, Jr., \& A.E. Grant (Eds.), Framing public life: Perspective on media and our understanding of the social world (pp. 7-32). New York, NY: Routledge.

Stephenson, J.S. (1985). Death, grief, and mourning. New York, NY: The Free Press. 
Sutton, W.A., McDonald, M.A., Milne, G.R., \& Cimperman, J. (1997). Creating and fostering fan identification in professional sports. Sport Marketing Quarterly, 6(1), 15-22.

Wann, D.L., \& Branscombe, N.R. (1993). Sports fans: Measuring degree of identification with their team. International Journal of Sport Psychology, 24(1), 1-17.

Zisook, S., \& Shear, K. (2013). Grief and bereavement: What psychiatrists need to know. World Psychiatry, 8(2), 67-74. PubMed ID: 19516922 doi:10.1002/j.2051-5545.2009. tb00217.x 